\title{
CANCER
}

\section{Serrated adenoma in familial adenomatous polyposis: relation to germline APC gene mutation}

\section{T Matsumoto, M lida, Y Kobori, M Mizuno, S Nakamura, K Hizawa, T Yao}

Gut 2002;50:402-404

See end of article for authors' affiliations

.....................

Correspondence to: T Matsumoto, Department of Endoscopic Diagnostics and Therapeutics, Kyushu University Hospital,

Maidashi 3-1-1,

Higashi-ku, Fukuoka 812-8582, Japan; matane@intmed2.med. kyushu-u.ac.jp

Accepted for publication 5 June 2001
Background: Serrated adenoma is a precursor of colorectal cancer.

Aim: To clarify possible genotype-phenotype correlations of serrated adenomas in familial adenomatous polyposis (FAP).

Patients: Eleven patients from eight families with FAP.

Methods: We performed total colonoscopy with multiple biopsies in patients. Neoplasia with a serrated glandular structure was regarded as a serrated adenoma. In each patient, germline mutations of the APC gene were determined. Colonic phenotype was compared with germline mutations of the APC gene.

Results: Serrated adenomas were found in three patients. These patients had macroscopic polyps $<100$ in number. Pedigrees with serrated adenomas had the truncating germline APC mutation at codon 161, 332, or 1556 while in the other pedigrees mutations were found between codons 554 and 1324

Conclusions: In FAP, serrated adenoma may be a phenotype characteristic of the attenuated form.
L ongacre and Fenoglio-Preiser ${ }^{1}$ reported on a colorectal adenoma of peculiar histology which has been referred to as a serrated adenoma. Although it has been reported that serrated adenomas are different from traditional adenomas with respect to immunohistochemical characteristics, ${ }^{2-5}$ genetic alterations of serrated adenomas have not been specified. We searched for serrated adenomas in patients with familial adenomatous polyposis (FAP) to elucidate the possible association between the adenomatous polyposis coli (APC) gene mutation and serrated adenoma.

\section{METHODS}

Eleven patients from eight families who had not been treated by prophylactic colectomy were enrolled in the present investigation.

Each subject underwent total colonoscopy with video endoscope (CF-230I, CF-240Z, or PCF-230 I; Olympus, Tokyo, Japan). For chromoscopy, $0.2 \%$ indigo-carmine solution was sprayed. The colorectum was observed precisely by a colonoscopist (TM) for number of polyps and polyps with a cerebriform surface, indicative of a serrated adenoma. ${ }^{6}$ In each subject, biopsy specimens were obtained from at least 10 lesions. A pathologist (TY) who was blind to the clinical and endoscopic features classified the histological sections. Histology revealing a serrated glandular pattern simulating hyperplasia and a prominence of nuclei was regarded as a serrated adenoma. ${ }^{1}$

Blood samples were obtained from all subjects, and mRNA and DNA were extracted from peripheral leucocytes. The APC gene was screened by polymerase chain reaction (PCR) based single strand conformation polymorphism (SSCP) and by the protein truncation test (PTT). When an aberrant band was detected by PCR-SSCP, it was sequenced by asymmetric PCR. In PTT, mRNA was reverse transcribed to cDNA and amplified with two primer pairs by PCR for proximal segments of the APC gene (codons 2-758). DNA was amplified with four primer pairs for distal segments of the APC gene (codons 658-2843). These PCR products were applied to rabbit reticulocyte lysate and translated into protein incorporation with ${ }^{38} \mathrm{~S}$ methionine. The synthesised protein was electrophoresed by

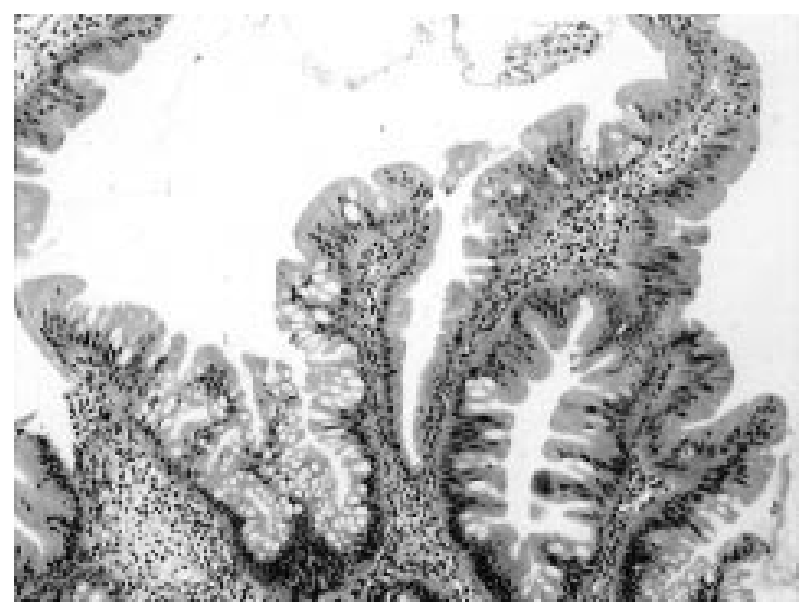

Figure 1 Histological findings of a serrated adenoma in case No 10. The lesion is composed of epithelial cells of prominent nuclei in serrated grandular structures. These findings are compatible with a serrated adenoma.

sodium dodecyl sulphate-polyacrylamide gel electrophoresis, and full length or truncated protein was determined.

\section{RESULTS}

Three lesions (3.7\%) from three unrelated subjects were diagnosed as serrated adenomas (table l, fig 1). The serrated adenomas were uniformly found in the rectum. These adenomas were small in size and pedunculated or semipedunculated in configuration (fig 2A). All serrated adenomas had a cerebriform surface (fig 2B).

Abbreviations: FAP, familial adenomatous polyposis; APC, adenomatous polyposis coli; PTT, protein truncation test; SSCP; single strand conformation polymorphism; LOH, loss of heterozygosity; MSI, microsatellite instability. 
Table 1 Histological diagnosis of polyps in familial adenomatous polyposis

\begin{tabular}{|c|c|c|c|c|c|c|c|}
\hline \multirow[b]{2}{*}{ Adenocarcinoma } & \multicolumn{2}{|l|}{ Tubular adenoma } & \multicolumn{2}{|c|}{ Tubulovillous adenoma } & \multirow{2}{*}{$\begin{array}{l}\text { Serrated } \\
\text { adenoma }\end{array}$} & \multirow[b]{2}{*}{ Hyperplastic polyp } & \multirow[b]{2}{*}{ Total } \\
\hline & Mild to moderate & Severe & Moderate & Severe & & & \\
\hline $3(2.2)$ & 112 (83.0) & $2(1.5)$ & $9(6.7)$ & $1(0.7)$ & $3(2.2)$ & $5(3.7)$ & $135(100)$ \\
\hline
\end{tabular}

Table 2 Comparison of colonic phenotype and adenomatous polyposis coli (APC) gene mutation in familial adenomatous polyposis

\begin{tabular}{|c|c|c|c|c|c|c|c|c|c|c|}
\hline \multirow[b]{2}{*}{$\begin{array}{l}\text { Case } \\
\text { No }\end{array}$} & \multirow[b]{2}{*}{ Family } & \multirow[b]{2}{*}{ Age* $^{*}(y)$} & \multirow[b]{2}{*}{ Sex } & \multicolumn{4}{|c|}{ Colorectal lesions } & \multicolumn{2}{|c|}{ APC gene mutation } & \multirow[b]{2}{*}{ PTT } \\
\hline & & & & $\begin{array}{l}\text { No of } \\
\text { polyps }\end{array}$ & $\begin{array}{l}\text { Predominant } \\
\text { site }\end{array}$ & $\begin{array}{l}\text { Invasive } \\
\text { cancer }\end{array}$ & $\begin{array}{l}\text { Serrated } \\
\text { adenoma }\end{array}$ & Exon (codon) & Predicted effect & \\
\hline & 1 & 64 & $\mathrm{~F}$ & $<20 \quad 1$ & Proximal & - & 1 & $4(161)$ & Nonsense & Positive \\
\hline & II & 37 & $M$ & $<50 \quad 2$ & Entire & + & 1 & 9 (332) & Nonsense & Positive \\
\hline & III & 20 & $\mathrm{~F}$ & $>10003$ & Distal & - & 0 & $13(554)$ & Nonsense & Positive \\
\hline & IV & 12 & $\mathrm{~F}$ & $>1004$ & Distal & - & 0 & 15 (1063) & FS; stop at codon 1129 & Positive \\
\hline & IV & 10 & $M$ & $>100 \quad 5$ & Distal & - & 0 & $15(1063)$ & FS; stop at codon 1129 & Positive \\
\hline & $\vee$ & 45 & $M$ & $>10006$ & Proximal & - & 0 & 15 (1251) & FS; stop at codon 1264 & Positive \\
\hline & $\mathrm{VI}$ & 29 & $\mathrm{~F}$ & $>10007$ & Entire & - & 0 & 15 (1324) & FS; stop at codon 1414 & Positive \\
\hline & $\mathrm{VI}$ & 27 & $\mathrm{~F}$ & $>10008$ & Entire & + & 0 & 15 (1324) & FS; stop at codon 1414 & Positive \\
\hline & VII & 46 & $\mathrm{~F}$ & $>10009$ & Distal & + & 0 & 15 (1324) & FS; stop at codon 1414 & Positive \\
\hline & VIIII & 21 & $M$ & $<10010$ & Entire & - & 1 & $15(1556)$ & FS; stop at codon 1558 & Positive \\
\hline & VIII & 16 & $\mathrm{~F}$ & $>10011$ & Entire & - & 0 & $15(1556)$ & FS; stop at codon 1558 & Positive \\
\hline
\end{tabular}

${ }^{*}$ Age at time of colonoscopy.

FS; frameshift mutation; PIT; protein truncation test.

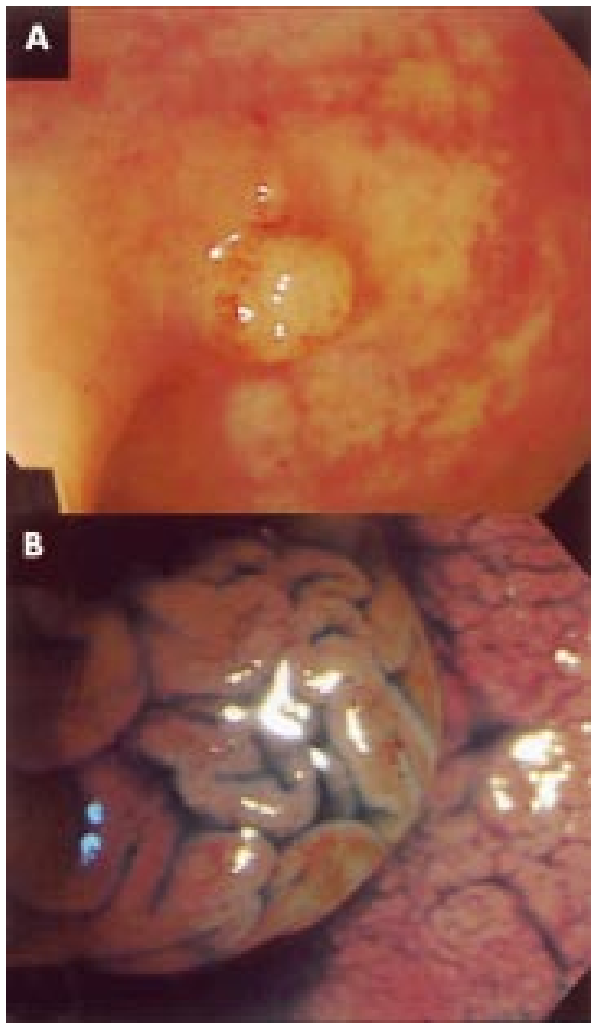

Figure 2 Endoscopic findings of a serrated adenoma in case No 10. There is a whitish semipedunculated polyp in the rectum (A). Under chromoscopy, the polyp has a cerebriform surface (B).

The colonic phenotype and APC gene mutations are compared in table 2. In three subjects with serrated adenomas (case Nos 1,2, and 10), the number of colorectal polyps was less than 100. Colonic polyposis was extremely sparse in two subjects (case Nos 1 and 2). The APC gene mutations in these subjects were located at the proximal site of the gene. In another subject with a serrated adenoma (case No 10), the polyps were found to be less than 100 in number, and the subject had an APC gene mutation at the most distal site (codon 1556) of all subjects examined.

\section{DISCUSSION}

There have been no previous reports of serrated adenomas in FAP. Even though our investigation was small in number, we found serrated adenomas in three of the 11 subjects examined. While there may be an argument that much sampling would increase the incidence of serrated adenomas, this seems to be unlikely because we preferentially examined polyps with a cerebriform surface that is characteristic of serrated adenomas. ${ }^{6}$ Thus we believe that the true incidence of serrated adenomas in FAP is actually lower than the value demonstrated in this study $(2.2 \%)$.

The concept of serrated adenoma proposes an independent pathway for the pathogenesis of colorectal cancer, namely the hyperplasia-dysplasia/adenoma-adenocarcinoma sequence. ${ }^{7-9}$ Whereas the K-ras mutation is shown to be rare in serrated adenomas of non-FAP patients, ${ }^{48}$ Hiyama and colleagues ${ }^{4}$ suggested that the p53 mutation is the initial genetic alteration. However, contradictory results for $\mathrm{p} 53$ have been reported by other investigators. ${ }^{2358}$ Recently, Rashid and colleagues $^{8}$ demonstrated loss of heterozygosity ( $\mathrm{LOH}$ ) of chromosome $\mathrm{lp}$ in polyps of hyperplastic polyposis but they did not detect $\mathrm{LOH}$ in serrated adenomas. In contrast, Iino and colleagues $^{10}$ found microsatellite instability (MSI) more frequently in serrated adenomas than in tubular adenomas. These observations suggest that the genetic alteration in serrated adenomas is a complex of multistep LOH and MSI mechanisms. Because the positive rate of serrated adenomas in our FAP patients (28\%) was 30 -fold higher than in the general Japanese population, ${ }^{11}$ the APC gene mutations seem to contribute to the pathogenesis in a certain proportion of serrated adenomas.

Colonic polyposis of less than 100 adenomas, which is referred to as attenuated FAP, has been identified recently. The 
responsible APC mutations have been shown to cluster at the proximal exons $4,5,9$, or at the distal $3^{\prime}$ end of exon $15 .{ }^{12}{ }^{13}$ The sparse colorectal polyposis and APC gene mutations of the three subjects with serrated adenomas were compatible with FAP of the attenuated form. These observations suggest that serrated adenoma may be a phenotype associated with less impaired function of the APC gene, ${ }^{14} 15$ and may be characteristic of attenuated FAP. Whereas serrated adenomatous polyposis of the colorectum, which has been suggested to be a more accurate term than hyperplastic polyposis, is shown to be unrelated to APC gene mutations, ${ }^{16}$ there may be a need to recognise serrated adenoma as a distinctive phenotype, even in FAP.

\section{Authors' affiliations}

T Matsumoto, Department of Endoscopic Diagnostics and Therapeutics, Kyushu University Hospital, Fukuoka, Japan

M lida, Y Kobori, M Mizuno, Division of Gastroenterology, Department of Internal Medicine, Kawasaki Medical School, Okayama, Japan S Nakamura, K Hizawa, Department of Medicine and Clinical Science, Graduate School of Medical Sciences, Kyushu University, Fukuoka, Japan T Yao, Department of Anatomic Pathology, Graduate School of Medical Sciences, Kyushu University, Fukuoka, Japan

\section{REFERENCES}

1 Longacre TA, Fenoglio-Preiser CM. Mixed hyperplastic adenomatous polyps/serrated adenoma: a distinct form of colorectal neoplasia. Am J Surg Pathol 1990;14:524-37.

2 Yao T, Kouzuki T, Kajiwara M, et al. "Serrated adenoma" of the colorectum with reference to its gastric differentiation and its malignant potential. J Pathol 1999:187:511-17.

3 Iwabuchi M, Sasano H, Hiwatashi N, et al. Serrated adenoma: a clinicopathological, DNA ploidy, and immunohistochemical study. Anticancer Res 2000;20:1141-7.
4 Hiyama T, Yokozaki H, Shimamoto F, et al. Frequent p53 gene mutations in serrated adenomas of the colorectum. J Pathol 1998;186:131-9

5 Kang $M$, Mitomi $H$, Sada $M$, et al. Ki-67, p53, and Bcl-2 expression of serrated adenomas of the colon. Am J Surg Pathol 1997;21:417-23.

6 Matsumoto T, Mizuno M, Shimizu M, et al. Serrated adenoma of the colorectum: colonoscopic and histologic features. Gastrointest Endosc 1999:49:736-42.

7 Ajioka Y, Watanabe H, Jass JR, et al. Infrequent K-ras codon 12 mutation in serrated adenomas of human colorectum. Gut 1998:42:680-4.

8 Rashid A, Houlihan PS, Booker S, et al. Phenotypic and molecular characteristics of hyperplastic polyps. Gastroenterology 2000;1 19:323-32.

9 Jass JR, Young J, Leggett BA. Hyperplastic polyps and DNA microsatellite unstable cancers of the colorectum. Histopathology 2000;37:295-301.

10 lino $\mathbf{H}$, Jass JR, Simms LA, et al. DNA microsatellite instability in hyperplastic polyps, serrated adenomas, and mixed polyps: a mild mutator pathway for colorectal cancer? J Clin Pathol 1999;52:5-9.

11 Matsumoto T, Mizuno M, Shimizu M, et al. Clinicopathological features of serrated adenoma: comparison with traditional adenoma. J Clin Pathol 1999;52:513-16.

12 Soravia C, Berk T, Madlensky L, et al. Genotype-phenotype correlations in attenuated adenomatous polyposis coli. Am J Hum Genet 1998;62:1290-301.

13 Giardiello FM, Brensinger JD, Luce MC, et al. Phenotypic expression of disease in families that have mutations in the 5 ' region of the adenomatous polyposis coli gene. Ann Intern Med 1997;126:514-19.

14 Su LK, Barnes CJ, Yao W, et al. Inactivation of germline mutant APC alleles by attenuated somatic mutations: a molecular genetic mechanism for attenuated familial adenomatous polyposis. Am J Hum Genet 2000;67:582-90.

15 Friedl W, Meuschel S, Caspari R, et al. Attenuated familial adenomatous polyposis due to a mutation in the 3' part of the APC gene: a clue for understanding the function of the APC protein. Hum Genet 1996;97:579-84.

16 Leggett BA, Devereaux B, Biden K, et al. Hyperplastic polyposis: association with colorectal cancer. Am J Surg Pathol 2001;25:177-84. 